\title{
Catering Convertible Design to Hedge Fund Demand
}

\author{
Eric Duca
}

\begin{abstract}
Towards the end of the $20^{\text {th }}$ century the primary convertible bond market changed from one where purchasers only held long positions in convertible bonds to one dominated by convertible bond arbitrageurs. In this paper we examine how this shift in demand has affected the motivations for firms to issue convertibles, by analyzing whether issuers adapt the design of their offerings to cater to the change in their clientele. We find that the design surprise more than doubles in the arbitrage period, as more issuers structure their offering to be more equity-like. Whereas the design surprise is positively related to underpricing, the sensitivity of the design is half as much in the period dominated by hedge funds as it is in the prior period. Convertible bond issuers in the hedge fund period can therefore quickly raise money without sacrificing much in terms of pricing of the issue. Our paper contributes to a recent stream of studies on the impact of buy-side characteristics on corporate finance transactions, and extends prior knowledge on the motivations for firms to issue convertible bonds.
\end{abstract}

January 15, 2014

Keywords: Capital Supply, Convertible Debt, Hedge Funds

\footnotetext{
* The author is from Colegio Universitario de Estudios Financieros. Corresponding author: Eric Duca, Colegio Universitario de Estudios Financieros (CUNEF), Serrana Anguita 8, 28004 Madrid, Spain. tel. +34-914480892. email: ericduca@cunef.edu.
} 


\section{Introduction}

Convertible bonds are hybrid securities that pay a fixed coupon but also offer the possibility of conversion into stock, thus combining features of both straight debt and equity. Between 1975 and 2007 companies issued convertibles worth around $35 \%$ of their total assets, compared with $49 \%$ raised from seasoned equity offerings and $11 \%$ raised from straight debt offerings. Convertibles can be structured to be more equity- or debtlike, allowing companies with high costs of attracting common equity or straight debt to access the capital markets. ${ }^{1}$

Until the end of the $20^{\text {th }}$ century, convertibles were largely purchased by investors requiring both a constant income stream and limited exposure to equities, such as insurance companies and pension funds (see, e.g., Lummer and Riepe, 1993). However, at the turn of the century a different type of buyer emerged. Convertible bond arbitrage hedge funds adopted a variety of strategies that targeted specific aspects of convertible bonds, while hedging away other risks (Calamos, 2003). These funds mainly participate in the new issues market, and consistently purchased approximately $80 \%$ of offerings since the year 2000 (see, e.g., Brown et al., 2010). Mitchell, Pedersen, and Pulvino (2007) note that the ability of arbitrageurs to hedge their positions effectively transformed the convertible bond into a security with significantly lower risk, thus reducing information asymmetries and enabling firms to quickly issue the convertible. This new

\footnotetext{
${ }^{1}$ Theoretical studies on convertible debt argue that convertibles are useful instruments for mitigating firmspecific, or aggregate, equity- and debt-related financing costs (Green, 1984; Brennan and Kraus, 1987; Brennan and Schwartz, 1988; Stein, 1992). Empirical evidence in line with this prediction in provided by Lewis, Rogalski, and Seward (1999, 2003), and Krishnaswami and Yaman (2008), among others.
} 
demand from hedge funds provided an added attraction for companies wishing to raise money, which was not related to the mitigation of equity- or debt-related financing costs. ${ }^{2}$

In this paper we examine whether the shift in the investor base, from traditionally long-only investors to convertible arbitrage hedge funds, encourages more opportunistic behavior from convertible issuers. We hypothesize that, following this shift, convertible issuers structure their offerings to appeal to hedge funds, rather than to mitigate equityand debt-related financing costs. We test our hypothesis by comparing issuance behavior in two periods, the pre-arbitrage period (1975-1999) and the arbitrage period (20002007), with the latter being the era dominated by convertible arbitrage hedge funds. Our analysis then proceeds in three steps: First we compare the design of a convertible issue with the likelihood that the issuer would have issued equity or debt instead, as predicted by a standard security choice model. ${ }^{3}$ We call the difference between the design of the bond and the equity-likeness of the issuer, the design surprise, and use this as the main variable in our analyses. We find that the design surprise more than doubles in the arbitrage period, as more issuers structure their offering to be more equity like. In the second step of our analyses we show that the design surprise is positively related to the demand from hedge funds, with issues being more equity-like. Calamos (2003) notes that convertible arbitrage hedge funds prefer issues that are more equity-like, since their strategies depend on bonds being sensitive to stock price movements. In the final part of our analyses, we find that issuers are able to structure their offerings in a way that caters to hedge funds because pricing has become less sensitive to the convertible bond design.

\footnotetext{
${ }^{2}$ There is anecdotal evidence that companies were reacting to hedge fund demand for new issues. For instance, Dinsmore, Dinsmore, and Finnican (2009) note that better-rated issuers were tempted by attractive pricing resulting from competition among hedge funds for new issues, while Pilliam (2004) reports that "... these investors wouldn't need to meet the company or understand what it does".

${ }^{3}$ We capture the design of the convertible bond through its delta, as explained in the text.
} 
Whereas the design surprise is positively related to underpricing, the sensitivity of the design is half as much in the period dominated by hedge funds than it is in the prior period. Convertible bond issuers in the hedge fund period can therefore quickly raise money without sacrificing much in terms of pricing of the issue.

Our results contribute to a recent strand of literature that examines how changes in the supply of funds influence corporate finance decisions and asset prices. Baker (2009) provides a framework for analyzing these supply effects on corporate decisions. There is also an increasing amount of empirical evidence. Baker and Wurgler (2004) show that managers cater to investor preferences for dividend-paying firms. Manconi and Massa (2009) find that firms with more fragmented ownership have more difficulties in catering to shareholder preferences for dividend payouts. Baker, Greenwood, and Wurgler (2009) obtain evidence that managers choose to maintain share prices at a low level in response to investor preferences for low-priced firms. Aghion and Stein (2008) provide a theory in which managers cater to the stock market's preferences for sales growth versus profit margins. Polk and Sapienza (2009) show that firms cater to investor preferences for the level of firm investment by altering their investment policy. Choi et al. (2010) and de Jong et al. (2013) document that increases in convertible arbitrage hedge fund flows have a positive impact on convertible debt issuance over the period 1996 to 2006.

Our results complement these studies by providing direct evidence of firms catering the design of convertible bonds to the specific requirements of hedge funds. We also show that the design is altered at the same time that it is less sensitive to pricing, allowing issuers to obtain cheaper funding when catering. These finding also have implications for traditional theories of issuance, which propose that firm design their convertible bonds to 
mitigate debt- and equity-related issuance costs. We show that firms may give less importance to these contracting costs when there are opportunities to raise capital quickly.

The remainder of the paper is structured as follows. In the next section we review the literature and develop the testable hypotheses. Section 3 describes the methodology and the data. In Section 4 we discuss our empirical results, while Section 5 concludes the paper.

\section{Literature Review}

In this section we review the main reference literature for our paper. A first strand of literature analyzes the motivations for firms to issue convertible debt and describes how convertibles can be designed to mitigate financing costs. A second strand of related papers examines the factors influencing the design of convertible bonds. We then turn our attention to literature that explores how the availability of investor capital influences corporate financing decisions.

\subsection{Motivations for convertible debt issuance}

The theoretical literature presents several viewpoints on why firms issue convertible debt. Mayers (1998) and Wang (2009) argue that convertibles are useful in reducing the issuance costs of sequential financing while at the same time mitigating overinvestment. Green (1984) demonstrates that, because of the convexity in their payoffs, convertible bonds are useful in reducing agency costs associated with risk shifting behavior of shareholders. Brennan and Schwartz (1988) show that convertible bonds substitute for straight debt if information asymmetry about the riskiness of the firm's assets is high, 
since convertibles are less sensitive to risk as a result of their option component. Convertibles reduce this problem, because if the firm is riskier than the convertible bond holders originally thought, they will profit from the higher risk by means of the conversion option component of their bonds. In the Stein (1992) framework, firms with high financial distress costs issue convertibles as an alternative to equity to alleviate equity-related adverse selection costs.

In aggregate, these theories predict that convertibles are most useful for firms with high costs of attracting equity or straight debt financing. Using a security choice model that incorporates convertible debt, equity, and straight debt, Lewis, Rogalski, and Seward (1999, 2003) find empirical evidence consistent with these hypotheses.

Another expectation for convertible debt is that, irrespective of firm-specific characteristics, issuance should be more attractive during windows with higher economywide costs for attracting equity or debt financing. A number of empirical studies have examined the impact of aggregate equity- and debt-related financing costs on the convertible debt issuance choice. Hoffmeister, Hays, and Kelley (1987), and Mann, Moore, and Ramanlal (1999) obtain evidence that aggregate convertible bond issuance is influenced both by equity market and bond market conditions. Krishnaswami and Yaman (2008) find that companies are more likely to substitute convertible debt for straight debt during periods with high economy-wide debt-related financing costs.

\subsection{Convertible bond structure}

Issuers can adjust the design of convertible bonds to make them more equity- or debtlike, thus further reassuring investors about their financing intentions. The most common 
convertible debt equity component measures used in the recent literature are variations on the delta measure of the Black-Scholes (1973) model (corrected for continuous dividend payments as suggested by Merton (1973)). Lewis, Rogalski, and Seward (1999) suggest the use of the factor $\mathrm{N}\left(\mathrm{d}_{2}\right)$ from the model of Black and Scholes (1973). This factor measures the conversion probability in a risk-neutral world. Other papers have used the delta measure from the same model. Delta measures the stock price sensitivity of a convertible bond to the underlying equity.

Lewis, Rogalski, and Seward (2003) use the conversion probability to distinguish convertible bonds in equity-like (conversion probability is greater than $60 \%$ ), hedge-like (conversion probability is between $40 \%$ and $60 \%$ ), and debt-like (conversion probability is lower than 40\%). They argue that convertibles are more equity-like when they substitute for equity, thus reducing financing costs arising from asymmetric information as in the theory of Stein (1992). Convertibles that are structured hedge-like are more suitable to deal with the asymmetric information problem that was suggested by Brennan and Schwartz (1988). Finally, convertibles that are structured more debt-like are used to reduce debt-related financing costs associated with the risk-shifting hypothesis of Green (1984). Krishnaswami and Yaman (2008) examine the firm-specific characteristics affecting delta and conclude that convertible bonds are more equity-like when bankruptcy costs and adverse selection costs are higher and more debt-like when information asymmetry is larger. Lewis and Verwijmeren, 2009) document that firm-specific and macroeconomic characteristics play an important role in explaining convertible debt design choices. 


\subsection{Impact of capital availability on corporate finance decisions}

In a neoclassical framework, markets are efficient and the supply of funds is perfectly elastic at a price that reflects fundamental value. A recent strand of literature, however, contends that changes in the supply of funds do have an effect on corporate finance decisions and asset prices. Baker (2009) argues that changes in the supply of capital can be caused by two factors, i.e., (i) changes in investor tastes (or preferences) and (ii) changes in the funds available to investors (he labels this second factor "limited intermediation"). We examine the impact of both elements on convertible bond issuance volumes and prices.

Several previous papers provide empirical evidence that corporate finance decisions and security prices are indeed influenced by investor tastes. Baker and Wurgler (2004) show that managers cater to investor preferences for dividend-paying firms. Manconi and Massa (2009) find that firms with more fragmented ownership have more difficulties in catering to shareholder preferences for dividend payouts. Baker, Greenwood, and Wurgler (2009) obtain evidence that managers choose to maintain share prices at a low level in response to investor preferences for low-priced firms. Aghion and Stein (2008) provide a theory in which managers cater to the stock market's preferences for sales growth versus profit margins. Polk and Sapienza (2009) show that firms cater to investor preferences for the level of firm investment by altering their investment policy.

\section{Data and Methodology}

We test the hypothesis about the shift of convertible bond buyers from long-only to arbitrage hedge funds by adopting a three-stage approach. In the first step we use a 
security choice model to examine how this shift in demand has altered the influence of convertible issuance as opposed to straight debt or equity. Next we analyze whether issuers adapt the design of their offerings to cater to the change in their clientele. Finally, we document the effect of the change in investor base on underpricing of convertible bond offerings.

Our analysis involves the comparison of two regimes: the era with long-only buyers (pre-arbitrage period) and the era dominated by convertible bond arbitrageurs (arbitrage period). The precise date when convertible bond arbitrage hedge funds surpassed longonly investors as the main purchasers of convertible bond issues is not clear-cut. Following Duca et al. (2013) we use 1975-1999 as our first period and 2000-2007 as the period dominated by hedge funds.

\subsection{Descriptive statistics}

Table 1 provides detailed descriptive statistics for characteristics of convertible debt, seasoned equity, over the entire sample period (1975-2007), as well as sub-periods. All the variables are defined in the appendix. Table 1 indicates that the predicted delta fell from the first period to the second, but the actual delta rose, leading to an increase in the design surprise from 0.13 to over 0.3 . At the same time, underpricing fell from $21.6 \%$ to $15.3 \%$. We also see that convertible issuers are larger in the second period, and tend to be more volatile. in the arbitrage period a wider variety of convertible issuers have tapped the convertible market, with both investment grade and unrated issues increasing. Announcement returns also became more negative, in line with the short selling pressure documented by Duca et al. (2013). In addition, Figure 1 shows that delta has remained 
rather stable above 0.7 over the whole period, whereas the predicted delta has fallen, as more debt-like issuers come to the market, leading to a larger design surprise (Figure 2).

$<<$ Please insert Table 1 here $>>$

$\ll<$ Please include Fig. 1. here $\gg$

$<<$ Please include Fig. 2. here $>>$

Table 2 shows that those firms with a high surprise are more likely to have issued debt instead: The predicted delta is lower, the probability of having issued debt in the previous 3 years is larger, and more are rated investment grade. Interestingly, profitability is larger, suggesting that these firms could be accessing the convertible market opportunistically rather than because they need the cash. Underpricing is also lower for these firms, while the announcement return is less negative, especially in the Arb period. Figure 3 shows that the main drop in delta is by those companies with a high delta (over $0.6)$.

$\langle<$ Please insert Table 2 here $>>$

$\langle<$ Please include Fig. 3. here $>>$ 


\subsection{Choice between convertible debt, seasoned equity, and straight debt issues}

In the first step of our analyses we use a security choice model to examine how the increasing importance of convertible bond arbitrageurs has influences the choice of companies to issue convertible bonds. We first estimate a logistic regression model for the choice between convertible debt and seasoned equity using firm characteristics and aggregate financing costs as explanatory variables. We estimate the model over the whole period (1975-2007), as well as the pre-arbitrage period (1975-1995) and arbitrage period (1996-2007) and compare the explanatory power of the model for the two sub-periods. The logistic regression model for the choice between convertible and equity issues is specified as:

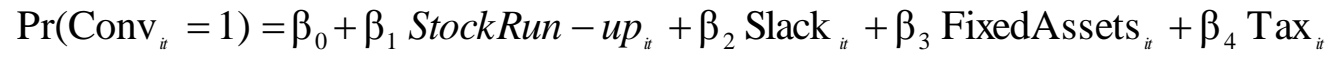
$+\beta_{5}$ MB $_{i t}+\beta_{6}$ Size $_{i t}+\beta_{7}$ Leverage $_{i t}+\beta_{8}$ AssetGrowh $_{i t}+\beta_{9}$ Stock Volat $_{i t}$ $+\beta_{10}$ Div Yield $_{i t}+\beta_{11}$ Rate $_{t}+\beta_{12}$ TermSpread $_{t}+\beta_{13}$ MktRun - up $p_{t}+\beta_{14}$ MktVolat $_{t}+v_{i t}$

Where Conv is a binary variable that takes a value of one if a convertible bond is issued in quarter $t$ by firm $i$, and a value of zero if straight debt is issued. ${ }^{4}$ The explanatory variables are as defined in the previous section. The most important observation is that companies are more likely to issue convertible bonds if hedge fund flows are larger.

$\langle<$ Please insert Table 3 here $>>$

\footnotetext{
${ }^{4}$ We treat multiple security issues by the same firm at different points in a quarter as separate observations.
} 
Columns (1) to (3) of Table 3 show estimated coefficients of the logistic regression model for the choice between convertible debt and straight debt. We examine the choice between convertibles and straight debt by estimating a similar logistic regression as in equation (3) with Conv now taking a value of one if a convertible bond is issued in quarter $t$ by firm $i$, and a value of zero if equity is issued.

With regards to the firm-specific characteristics for both the pre-arbitrage period (Column 5) and arbitrage period (Column 6), we find a significantly positive coefficient for Stock Run-up and Slack. Convertible bond issuers have significantly less fixed assets than debt issuers, supporting Green's (1984) argument that convertible debt reduces agency problems associated with risk shifting. As expected, convertible issuers also have less to gain from tax benefits. The coefficients of Size and Leverage are also significantly negative. Finally, in line with previous studies, we find that convertible issuers are riskier than straight debt issuers (significantly higher Stock Volat). Surprisingly, in the arbitrage period (Column 6), issuers prefer convertibles to straight debt when general interest rates (rate) and Mkt Volat are lower, perhaps as a result of firm-specific characteristics becoming more important. ${ }^{5}$ The model also offers more explanatory power in the arbitrage period than in the pre-arbitrage period.

Columns (4) to (6) of Table 3 show that estimated coefficients of the logistic regression model for the choice between convertible debt and seasoned equity. We find that, across all periods, convertible issuers have a significantly lower Stock Run-up and Fixed Assets, and a significantly higher Size and Stock Volat than equity issuers. These findings are largely consistent with those of previous studies (see, e.g., Lewis, Rogalski

\footnotetext{
${ }^{5}$ Krishnaswami and Yaman (2008), in contrast, find that convertibles are more likely to be issued during periods of high interest rates.
} 
and Seward, (1999, 2003) and Krishnaswami and Yaman (2008)). The Adjusted Rsquared increases substantially from $6.3 \%$ in the pre-arbitrage period to $13.6 \%$ in the arbitrage period. In addition Slack and Fixed Assets become significant, which is in line with our predictions. The last result indicates that in this period the security choice model is better explained by firm-specific financing costs.

\subsection{Convertible debt design}

In the second step of our analysis, we examine whether issuers adapt the design of their offerings to cater to the change in their clientele. We run the following OLS regressions of design on firm-specific and economy-wide proxies for financing costs, for the three periods:

Design $_{i t}=\beta_{0}+\beta_{1}{\text { StockRun }-u p_{i t}}+\beta_{2}$ Slack $_{i t}+\beta_{3}$ FixedAssets $_{i t}+\beta_{4}$ Tax $_{i t}$ $+\beta_{5} \mathrm{MB}_{i t}+\beta_{6}$ Size $_{i t}+\beta_{7}$ Leverage $_{i t}+\beta_{8}$ AssetGrowth $_{\mathrm{it}}+\beta_{9}$ Stock Volat $_{i t}$

$+\beta_{10}$ Rate $_{t}+\beta_{11}$ TermSpread $_{t}+\beta_{12}$ MktRun $-u p_{t}+\beta_{13}$ MktVolat $_{t}+v_{i t}$

Where Design refers to either the convertible bond delta, which measures the sensitivity of the bond's price to changes in underlying stock price, or the delta surprise, both defined in the appendix.

$<<$ Please insert Table 4 here $>>$

The first two columns of Table 4 show the estimates from a regression where the dependent variable is the convertible delta. The coefficients in Column (2) indicate that companies structure the convertible to be more equity like when there are is more hedge 
fund demand. We also see that to some extent firms design the convertible more equitylike (higher delta) to mitigate equity-related costs. Delta is positively related to $M B$, Leverage, Stock Volat, and negatively related to Size. The negative coefficient for Tax seems counterintuitive.

In Columns (3) and (4) of Table 4 we show the estimates from a regression where the dependent variable is the delta surprise. We also see that companies structure the convertible to be more equity like (larger surprise) when there are is more hedge fund demand. This would suit arbitrageurs employing arbitrage strategies, even though issuers should have lower deltas to address financing costs.

\subsection{Underpricing and stockholder wealth effects of convertible bond announcements}

In the final part of our analysis we examine the effect of the change in investor base on underpricing and stockholder wealth effects (announcement day abnormal returns) of convertible bond offerings. We estimate the following regressions of firm-level announcement returns on firm-specific and economy-wide proxies for financing costs, for the three periods:

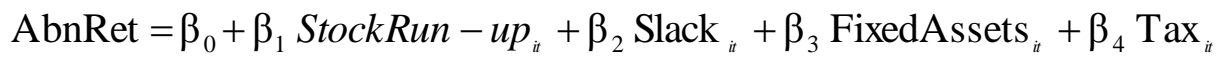

$$
\begin{aligned}
& +\beta_{5} \mathrm{MB}_{i t}+\beta_{6} \text { Size }_{i t}+\beta_{7} \text { Leverage }_{i t}+\beta_{8} \text { AssetGrowh }_{\text {it }}+\beta_{9} \text { Stock Volat }_{i t} \\
& +\beta_{10} \text { Proceeds }_{i t}+\beta_{11} \text { Delta }_{i t}+\beta_{12} \text { Rate }_{t}+\beta_{13} \text { TermSpread }_{t}+\beta_{14} \text { MktRun }-u p_{t} \\
& +\beta_{14} \text { MktVolat }_{t}+v_{i t}
\end{aligned}
$$


Where AbnRet measure either underpricing (Table 5) or the abnormal stock returns (Table 6) around the announcement dates of new convertible bond issues. Further control variables for underpricing as described in the appendix.

Column 2 of table 5 indicates that underpricing is larger as the design surprise increases, but the estimated coefficient is smaller for the arbitrage period (Column 3). The same applies to delta (comparing columns 5 and 6) This provides evidence that convertible arbitrageurs prefer equity-like securities and are willing to accept lower underpricing for issuers that structure them in this way.

We also find a significant positive coefficient for Rate, and significant negative coefficients for TermSpread, MktRunup and MtkVolat. At the firm level, we find significantly higher initial underpricing for firms having more volatile returns (StockVolat), and a smaller size (LogAssets). The significantly negative coefficient for DivYield suggests that firms with many valuable growth opportunities (as proxied by low dividends) issue bonds that are more underpriced. As expected, underpricing is significantly positively influenced by Dilution, and significantly negatively influenced by Moneyness. Rating has a counterintuitive negative sign, suggesting that bonds with a higher credit rating (scale closer to one) are more underpriced.

$<<$ Please insert Table 5 here $>>$

In Column (3) of Table 6 we see that announcement abnormal returns (AbnRet) in the pre-arbitrage period are related positively to the design surprise, providing further support to the evidence in table 5. AbnRet is positively related to Tax, and negatively affected by 
$M B$ and Stk Volat. The intercept in the arbitrage period is significantly negative, indicating that the downward shift in AbnRet documented in Table 1 cannot be explained by firm-specific or aggregate financing costs.

$<<$ Please include Table 6 here $>>$

\section{Conclusions}

Convertible bonds have traditionally been used as an alternative to equity or debt financing by firms with high equity- or debt-related financing costs (Green, 1984; Brennan and Kraus, 1987; Brennan and Schwartz, 1988; Stein, 1992). Investors in these securities typically purchase convertibles as part of a balanced portfolio. In the mid1990s, however, there was a shift in the investor base, with convertible arbitrage hedge funds purchasing most of the new issues. These arbitrageurs adopt a variety of strategies that target specific aspects of convertible bonds, while hedging away other risks, thus reducing information asymmetries and enabling firms to quickly issue the convertible.

In this paper we show that the shift in the investor base, from traditionally long-only investors (pre-arbitrage period) to convertible arbitrage hedge funds (arbitrage period), presented opportunities for a wider variety of issuer to tap the primary market for convertibles. This is most evident in the design of offerings, which has become more equity-like to satisfy convertible hedge fund preferences. We also show that the design is altered at the same time that it is less sensitive to pricing, allowing issuers to obtain cheaper funding when catering. Our results contribute to a recent strand of literature that 
examines how changes in the supply of funds influence corporate finance decisions and asset prices (see, e.g. Baker, 2009). 


\section{References}

Aghion, P., Stein. J., 2008. Growth vs. Margins: Destabilizing Consequences of Giving the Stock Market What it Wants. Journal of Finance, 63, 1025-1058.

Baker, M., 2009. Capital Market-Driven Corporate Finance. Annual Review of Financial Economics 1, 181-205.

Baker, M., Greenwood, R., Wurgler, J., 2009. Catering through Nominal Share Prices. Journal of Finance 64, 2559-2590.

Baker, M., Wurgler, J., 2004. A Catering Theory of Dividends. Journal of Finance 59, 1125-1165.

Black, F., Scholes, M., 1973, The pricing of options and corporate liabilities. The Journal of Political Economy 81, 673-654.

Brennan, M., Kraus, A., 1987. Efficient financing under asymmetric information. The Journal of Finance 42, 1225-1243.

Brennan, M., Schwartz, E., 1988. The case for convertibles. Journal of Applied Corporate Finance 1, 55-64.

Brown, S., Grundy, B., Lewis, C., Verwijmeren, P., 2012. Convertibles and hedge funds as distributors of equity exposure. Review of Financial Studies 25, 3077-3112

Brown, S.J., Warner, J.B., 1985, Using daily stock returns: The case of event studies, Journal of Financial Economics 14, 3-31.

Burlacu, R., 2000. New evidence on the pecking order hypothesis: The case of French convertible bonds. Journal of Multinational Financial Management 10, 439--459.

Calamos, N., 2003, Convertible Aribtrage: Insights and Techniques for Successful Hedging. John Wiley \& Sons, Hoboken, New Jersey.

Choe, H., Masulis, R., Nanda, V., 1993. Common stock offerings across the business cycle: theory and evidence. Journal of Empirical Finance 1, 3-31.

Choi, D., Getmansky, M., Henderson, B., Tookes, H., 2010. Convertible bond arbitrageurs as suppliers of capital. Working Paper (Yale International Center for Finance).

Choi, D., Getmansky, M., Tookes, H., 2009. Convertible bond arbitrage, liquidity externalities and stock prices. Journal of Financial Economics, 2, 227-251..

de Jong, A., Duca, E., Dutordoir, M., 2013. Do Convertible Bond Issuers Cater to Investor Demand?, Financial Management 42, pp. 41-78. 
De Jong, A., Dutordoir, M., Verwijmeren, P., 2011. Why do convertible issuers simultaneously repurchase stock? An arbitrage-based explanation. Journal of Financial Economics 100, 113-129.

Dinsmore, T., Dinsmore, J., Finnican, P. 2009. A review of the convertible securities market. Dinsmore Capital Management.

Duca, E., Dutordoir, M., Veld, C., Verwijmeren P., Why Are Convertible Bond Announcements Associated with Increasingly Negative Abnormal Stock Returns? An Arbitrage-Based Explanation, Journal of Banking and Finance 36 (2012), pp. 2884-2899.

Dutordoir, M., Van de Gucht, L., 2007. Are there windows of opportunity for convertible debt issuance? Evidence for Western Europe. Journal of Banking and Finance 31, 282846.

Eckbo, B., Masulis, R., 1995. Seasoned Equity Offerings: A Survey. In R. Jarrow, V. Maksimovic, and B. Ziemba (Eds.), Finance: Series of Handbooks in Operations Research and Management Science. North-Holland, Amsterdam, 1017-1072.

Green, R., 1984. Investment incentives, debt, and warrants. Journal of Financial Economics 13, 115-136.

Hoffmeister, J., Hays, P., Kelley, G., 1987. Conditions affecting the timing of convertible bond sales. Journal of Business Research 15, 101-106.

Hughes, J., 2009. An appetite for convertibles.” Financial Times, June 18.

Jen, F., Choi, D., Lee, S.-H., 1997. Some new evidence on why companies use convertible bonds. Journal of Applied Corporate Finance 10(1), 44-53.

Kang, J., Lee, Y., 1996. The pricing of convertible debt offerings. Journal of Financial Economics 41, 231-248.

Kim, Y., Stulz, R., 1992. Is there a global market for convertible bonds? Journal of Business 65, 75-91.

Korajczyk, R., Levy, A., 2003. Capital structure choice: macroeconomic conditions and financial constraints. Journal of Financial Economics 68, 75-109.

Krishnaswami, S., Yaman, D., 2008. The role of convertible bonds in alleviating contracting costs. Quarterly Review of Economics and Finance 48, 792-816.

Lewis, C.M., Rogalski, R.J., Seward, J.K. 1999. Is convertible debt a substitute for straight debt or for common equity? Financial Management 28, 5-27. 
Lewis, C.M., Rogalski, R.J., Seward, J.K, 2003. Industry conditions, growth opportunities and market reactions to convertible debt financing decisions. Journal of Banking and Finance 27, 153-181.

Lewis, C.M., Verwijmeren, P., 2011. Convertible Security Design and Contract Innovation. Journal of Corporate Finance 17, 809-831.

Liu. J., Switzer, L.N., 2009. Liquidity risk, firm risk, and issue risk premium effects on the abnormal returns to new issues of convertible bonds. Working Paper. Concordia University.

Loncarski, I., ter Horst, J., Veld. C., 2008. Why do companies issue convertible bonds? An empirical analysis for the Canadian market. Canadian Journal of Administrative Sciences 25, 214-236.

Loncarski, I., Ter Horst, J., Veld, C., 2009. The rise and demise of the convertible arbitrage strategy. Financial Analysts Journal, 65(5), 35-50.

Lowry, M., 2003. Why does IPO volume fluctuate so much? Journal of Financial Economics 67, 3-40.

Lucas, D., McDonald. R., 1990. Equity issues and stock price dynamics. Journal of Finance 45, 1019-1044.

Lummer, S., Riepe M., 1993. Convertible bonds as an asset class; 1957-1992. Journal of Fixed Income 3, 47-57.

Manconi, A., Massa, M., 2009. A Servant to Many Masters: Competing Shareholder Preferences and Limits to Catering. Insead Working Paper.

Mann, S., Moore, W., Ramanlal, P., 1999. Timing of convertible debt issues. Journal of Business Research 45, 101-105.

Masters, B., 2009. Companies return to convertibles. Financial Times, May 11, 2009.

Mayers, D., 1998. Why firms issue convertible bonds: the matching of financial and real investment options. Journal of Financial Economics 47, 83-102.

Merton, R., 1973. Theory of rational option pricing. Bell Journal of Economics and Management Science 4, 141-183.

Mitchell, M., Pedersen, L. Pulvino, T., 2007. Slow moving capital. American Economic Review 97, 215-220.

Monnelly, M., 2003. The rise and fall of convertible arbs. Euromoney. November 2003. 
Myers, S.C., Majluf, N.S., 1984. Corporate financing and investment decisions when firms have information that investors do not have. Journal of Financial Economics 13, 187--221.

Pernambuco, A., 2003. Consider convertible arbitrage to balance performance, risk. Financial Executive. May 2003.

Polk, C., Sapienza, P., 2009. The Stock Market and Corporate Investment: A Test of Catering Theory. Review of Financial Studies 22, 187-217.

Pulliam, S., 2004. Mixed blessing: How hedge-fund trading sent a company's stock on wild ride. Wall Street Journal December 28, A1.

Ranaldo, A., Eckmann A., 2004. Convertible bonds: characteristics of an asset class. Working Paper (UBS).

Stein, J., 1992. Convertible bonds as backdoor equity financing. Journal of Financial Economics 32, 3-21.

Wang, S. 2009. Convertibles in sequential financing. Review of Finance 13, 727-760. 


\section{Appendix A: Detailed definitions of issuer-specific, issue-specific, and}

macroeconomic variables included in the analysis

\section{A.1. Proxies for firm-level financing costs}

We include the following standard firm-specific financing costs proxies (see, e.g., Lewis, Rogalski, and Seward, 1999, 2003; Krishnaswami and Yaman, 2008). Stock price data are obtained from CRSP. Trading days are measured relative to the convertible bond announcement date. Firm characteristics are retrieved from the Compustat Fundamentals Annual database, and measured at the end of the fiscal year prior to the offering, unless mentioned otherwise. The symbol "\#” denotes a Compustat data item:

Stock Run-up: The cumulative stock return over the window $(-120,-40)$ relative to the announcement date. As shown by Lucas and McDonald (1990), a pre-announcement stock run-up can reflect lower equity-related adverse selection costs.

Slack: Cash and short-term investments (\# 1) divided by total assets (\# 6). Financial slack acts as a measure for adverse selection costs, since firms with higher slack could engage in wasteful use of resources.

Fixed Assets: Calculated as plant, property and equipment (\# 8) divided by total assets. Firms with a higher proportion of tangible assets are assumed to have lower financial distress costs. Asset tangibility could also be negatively associated with information asymmetry.

Tax: Captures the tax liabilities benefit associated with issuing debt and is computed as income tax (\# 16) divided by total assets.

$M B$ : Market to book value, calculated as the number of shares (\# 24) multiplied by the share price (\# 25), divided by the book value of common equity (\# 60). This variable 
can proxy for growth opportunities, but may also capture asymmetric information and/or underinvestment problems.

Size: Calculated as the natural logarithm of total assets (\# 6). Larger firms are assumed to face smaller information asymmetries regarding their value and risk.

Leverage: Long-term debt (\# 9) divided by total assets. Higher leverage is assumed to be associated with higher financial distress and risk-shifting costs.

Asset Growth: Growth in total assets (\# 6) calculated over the year prior to the offering. High-growth firms are hypothesized to be more likely to engage in risk-shifting behavior.

Stock Volat: The volatility in the stock price prior to issue, calculated over days -240 to -40 , and expressed in annualized terms.

Div Yield: The dividend yield, defined as dividend per share (\# 26) divided by the stock price (\# 199). Calamos (2003) notes that hedge funds prefer companies that do not pay dividends so this variable is expected to negatively effect the probability of issuing convertibles.

Proceeds: The relative size of the convertible debt offering, calculated as the issue proceeds (obtained from SDC) divided by the total assets of the firm (\# 6). In line with Lewis, Rogalski, and Seward (1999, 2003), and Dutordoir and Van de Gucht, 2007, we expect larger offerings to induce more negative announcement returns due to higher external financing costs.

We also obtain data on the bond rating of each issue from Moody's credit ratings, or equivalent Standard and Poor's ratings converted to a Moody's rating (both obtained 
from SDC). We follow Kang and Lee (1996) in classifying investment grade issues as those having a Moody's rating of Baa3 or higher.

\section{A.2. Macroeconomic financing costs proxies}

Next to the proxies for investor demand, we include several widely-used macroeconomic variables to control for intertemporal variations in general debt- and equity-related contracting costs. All variables are obtained from Datastream. The real interest rate (Rate) serves as a proxy for bankruptcy risk, as in Krishnaswami and Yaman (2008). This variable is calculated as the difference between yields on 10-year U.S. Treasury Bonds and the inflation rate, defined as the continuously-compounded annual change in the U.S. consumer price index. Following Korajczyk and Levy (2003), we control for business conditions and expected investment opportunities by including the term spread (Term Spread), defined as the difference between yields on 10-year U.S. Treasury Bonds and 3-month U.S. Treasury Bills. Both the real interest rate and the term spread are averaged over the 3 months prior to the convertible bond offering. The market run-up (Mkt Run-up), calculated as the return on the S\&P 500 index over the quarter preceding the issue, is included to control for general market conditions as in Korajczyk and Levy (2003) and Lowry (2003). In periods of heightened market uncertainty, adverse selection costs are higher (Choe, Masulis, and Nanda, 1993). To capture uncertainty about market returns, we include the annualised market return volatility (Mkt Volat), calculated using daily returns on the S\&P 500 index over the quarter preceding the issue. 


\section{A.3. Convertible delta}

We measure the equity-likeness of the structure of convertible issues by using delta, as in recent papers (see, e.g., Dutordoir and Van de Gucht, 2007; Burlacu, 2000). Delta describes the sensitivity of a convertible's price to changes in underlying stock price. A high delta means that the convertible bond is very sensitive to its underlying stock value and, therefore, is similar to equity. The calculation of delta is as in Liu and Switzer (2009):

Delta $=e^{-q T} N\left(\frac{\ln \left(\frac{S}{X}\right)+\left(r-q+\frac{\sigma^{2}}{2}\right) T}{\sigma \sqrt{T}}\right)$

Where:

$N(\bullet)$ is the cumulative distribution function of standard normal distribution $\Phi(\bullet)$ is the probability distribution function of standard normal distribution $S$ is the price of the underlying stock is averaged between days -12 and -2 relative to the issue date and is taken from CRSP

$X$ is the exercise price of the convertible bond, obtained from the SDC database.

$\sigma$ is the volatility of issues is defined as the annualized standard deviation calculated from returns over trading days $t-240$ to $t-40$ before the issue $r$ is the yield on 10-year U.S. government bonds, obtained from CRSP $T$ is the time to maturity of the option in years, obtained from the SDC database 
$q$ is the dividend yield measured at fiscal year-end preceding the announcement date, obtained from Compustat

\section{A.4. Predicted delta and Design surprise}

We calculate the predicted security type that a convertible issuer would have chosen had they issued debt or equity instead as follows: First we estimate a logistic regression model for the choice between straight debt and seasoned equity for all equity and debt issues made by the entire universe of compustat firms, over the period 1975-2007. Then we use the estimated coefficients to fit the predicted type to convertible bond issuers. We estimate the model using the following firm characteristics and aggregate financing costs as explanatory variables:

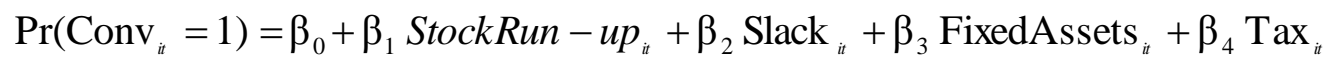
$+\beta_{5} \mathrm{MB}_{i t}+\beta_{6}$ Size $_{i t}+\beta_{7}$ Leverage $_{i t}+\beta_{8}$ AssetGrowh $_{\mathrm{it}}+\beta_{9}$ Stock Volat $_{i t}$

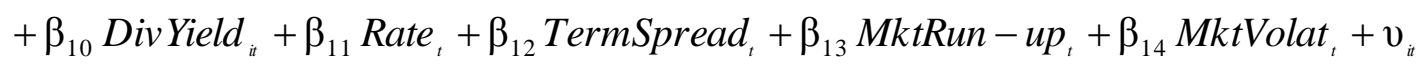

Where Conv is a binary variable that takes a value of one if equity is issued in quarter $t$ by firm $i$, and a value of zero if debt is issued. ${ }^{6}$ The explanatory variables are as defined in the Appendix.

The Design Surprise is then the difference between the actual delta and the predicted delta.

\section{A.5. Flows into convertible arbitrage hedge funds}

\footnotetext{
${ }^{6}$ We treat multiple security issues by the same firm at different points in a quarter as separate observations.
} 
We measure hedge fund flows (Hflows) in a similar way as Choi et al. (2010). First, we calculate dollar flows for each fund using the change in total net assets over quarter $\mathrm{t}$ adjusted for the returns of the fund, as in Equation (1). We then aggregate flows and total net assets across funds for each quarter and divide the change in total flows by total lagged assets to obtain percentage quarterly fund flows [Equation (2)].

$$
\begin{aligned}
& \text { Dollar Flow }_{\mathrm{it}}=\text { Assets }_{\mathrm{it}}-\text { Assets }_{\mathrm{it}-1}\left(1+\mathrm{r}_{\mathrm{it}}\right) \\
& \text { Percentage Flows } \\
& \mathrm{t}=\frac{\sum_{\mathrm{i}=1}^{\mathrm{N}} \text { Dollar Flow }_{\mathrm{it}}}{\sum_{\mathrm{i}=1}^{\mathrm{N}} \text { Assets }_{\mathrm{it}-1}}
\end{aligned}
$$

In these equations, Assets ${ }_{i t}$ refers to total net assets of each fund in quarter $t$, and $r_{i t}$ is the asset return from quarter $\mathrm{t}-1$ to $\mathrm{t}$, calculated from the net asset value of each fund.

\section{A.6. Convertible bond underpricing}

As in de Jong, Dutordoir, and Verwijmeren (2011), we adopt the following definition of convertible bond offering discounts (OD):

$$
\mathrm{OD}=\frac{\text { TheorPrice }- \text { IssuePrice }}{\text { TheorPrice }}
$$

In Equation (3), TheorPrice refers to the theoretical price of the bond, and IssuePrice refers to actual price at which the bond is issued (obtained from SDC). 
To calculate the theoretical convertible bond price, we use the Tsiveriotis and Fernandes (1998) model. Tsiveriotis and Fernandes essentially use a binomial-tree approach to model the stock price process and decompose the total value of a convertible bond into an equity component and a straight debt component. Since the straight debt part is subject to default, it needs to be discounted at a risk-adjusted rate. The residual equitylike part is default-free and can be discounted at the risk-free rate. The Tsiveriotis and Fernandes model is widely-used in other academic studies that examine convertible bond underpricing (Ammann, Kind, and Wilde, 2003; Chan and Chen, 2007; Loncarski, ter Horst, and Veld, 2009; de Jong, Dutordoir, and Verwijmeren, 2010). Zabolotnyuk, Jones, and Veld (2010) point out that the method is also popular among practitioners.

We use the following input variables in the model (all measured as of the convertible bond issue date, unless otherwise mentioned): yield on U.S. government bonds of which the maturity most closely matches the maturity of the convertible bond (obtained from CRSP); Moody's credit ratings or equivalent Standard and Poor's ratings converted to a Moody's rating [both obtained from SDC. We assign a rating of BAA2 to unrated convertibles, as in Loncarski, ter Horst, and Veld (2009)]; credit spreads of similarlyrated corporate straight debt (obtained from Datastream); conversion ratios and call schedules (obtained from SDC); dividend yield for the fiscal year preceding the announcement date [calculated as dividend per share (\#26) divided by the stock price (\#199)], price of the underlying stock averaged between trading days -12 and -2 (obtained from CRSP); and annualized stock return volatility calculated from daily stock returns over the window $(-240,-40)$. We can calculate offering discounts from 1991 onwards, since credit spreads are not available on Datastream prior to this year. 
Figure 1. Quarterly average delta and predicted delta of convertible bond issues

This figure shows the quarterly average delta and predicted delta of convertible issuers between January 1975 and December 2007. The construction of the variables is defined in Appendix A3 and A4. We first calculate the variable for each firm and then average across firms issuing in the same quarter.

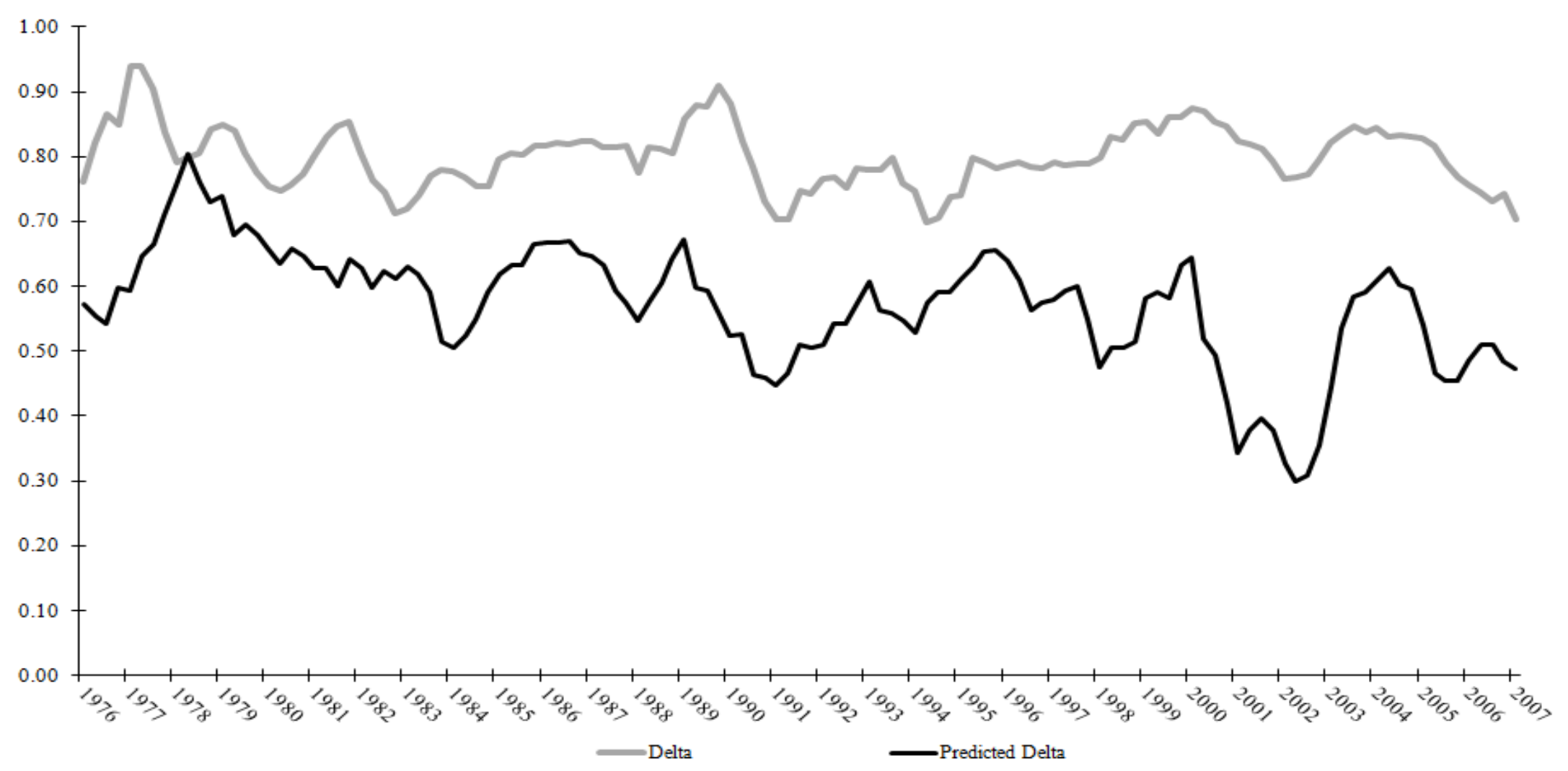


Figure 2. Quarterly average design surprise of convertible bond issues

This figure shows the quarterly average design surprise of convertible issuers between January 1975 and December 2007 . The Design Surprise is the difference between the actual delta and the predicted delta.

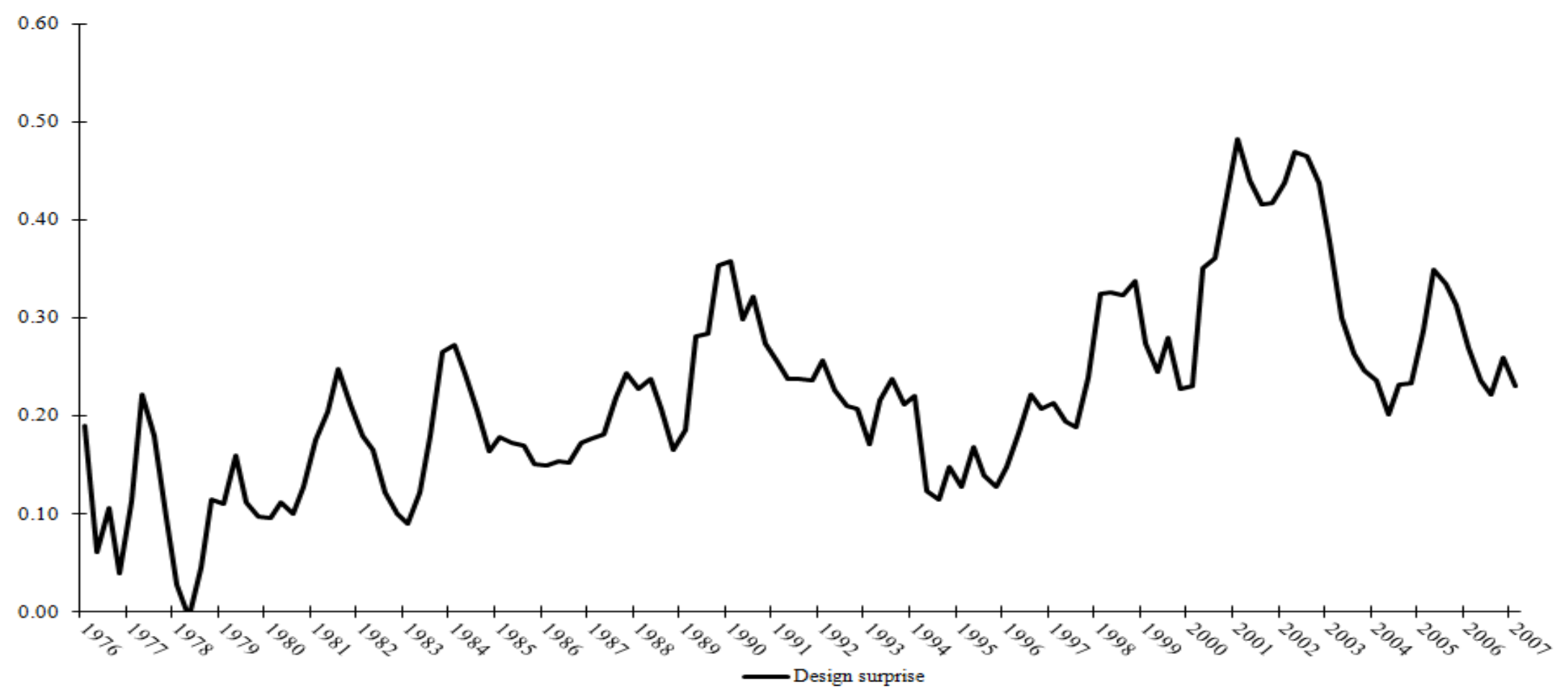


Figure 3. Annual average underpricing of convertible bond issues

This figure shows the Annual average underpricing of convertible issuers between January 1975 and December 2007 . We first calculate abnormal returns for each firm and then average across firms issuing in the same year. Underpricing_high refers to the underpricing of issues having high delta (over 0.6) and Underpricing_low refers to the underpricing of issues having low delta (below $0.6)$

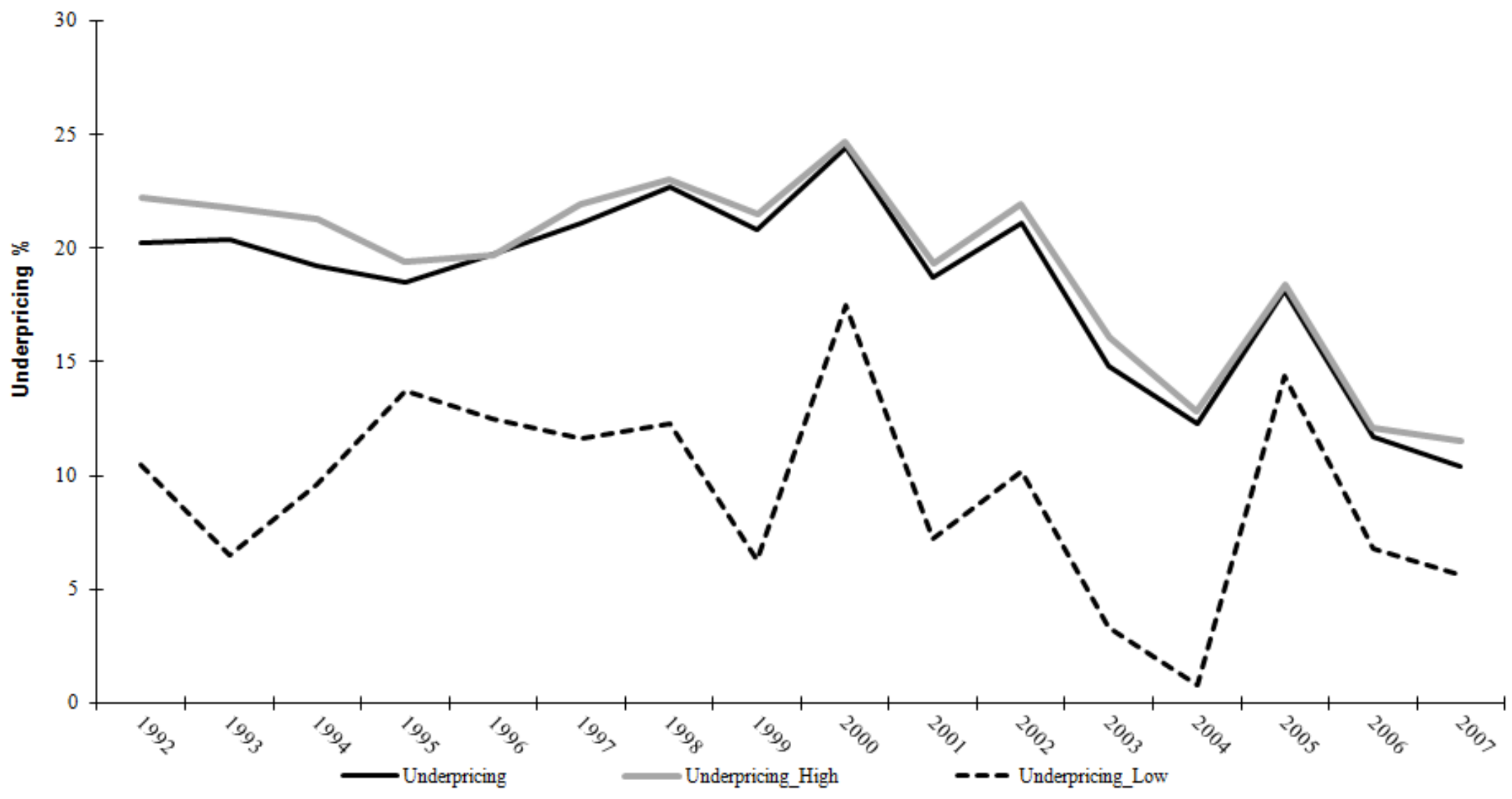


Table 1: Summary statistics for convertible issuers by period

Panel A provides descriptive statistics for firm specific characteristics of convertible, equity and straight debt issues (\# indicates a Compustat data item): Stock Run-up is the cumulative stock return over the window $(-120,-40)$ relative to the announcement date. Slack is calculated as cash and short-term investments (\# 1) divided by total assets (\# 6). Fixed Assets is calculated as plant, property and equipment (\# 8) divided by total assets. Tax is the tax liabilities benefit associated with issuing debt (\# 16) divided by total assets. $M B$ refers to the market to book value and is calculated as the number of shares (\# 24) multiplied by the share price (\# 25), divided by common equity (\# 60). Size is calculated as the natural logarithm of total assets (\# 6). Abs Size is calculated as the absolute value of total assets in millions of dollars (\# 6). Leverage is book leverage, measured as long-term debt (\# 9) divided by total assets. Asset Growth is calculated as the percentage growth in assets over the year prior to the offering. Stock Volat is the annualized standard deviation of the stock return, calculated using daily returns over the window $(-120,-40)$ relative to the announcement date. Proceeds measures the relative size of the convertible debt offering, calculated as the issue proceeds divided by the total assets of the firm (\# 6). Abs Proceeds measures the absolute value of the issue proceeds in millions of dollars. Div Yield is defined as dividend per share (\# 26) divided by the stock price (\# 199). Panel B reports the shareholder wealth effects of convertible, equity and straight debt issues across sub-periods. AbnRet captures average percentage abnormal stock returns measured over the window (-1, 0) relative to the announcement date using standard event study methodology. The Pre-arbitrage period spans 1975-1995 and refers to the period before the surge in convertible arbitrage hedge funds, while the Arbitrage period spans 1996-2007 and refers to the era when convertible arbitrageurs were the predominant purchasers of convertible debt issues. 


\begin{tabular}{|c|c|c|c|c|c|c|c|c|c|}
\hline & \multicolumn{3}{|c|}{$\begin{array}{l}\text { Entire period }(1975-2007) \\
\qquad(\mathrm{N}=1,756)\end{array}$} & \multicolumn{3}{|c|}{$\begin{array}{l}\text { Pre-arb period (1975-1999) } \\
\qquad(\mathrm{N}=1,040)\end{array}$} & \multicolumn{3}{|c|}{$\begin{array}{l}\text { Arb period (2000-2007) } \\
\qquad(\mathrm{N}=716)\end{array}$} \\
\hline & Mean & Median & Std. Dev. & Mean & Median & Std. Dev. & Mean & Median & Std. Dev. \\
\hline \multicolumn{10}{|c|}{ Firm-Specific Characteristics } \\
\hline StockRunup & 0.172 & 0.145 & 0.234 & 0.167 & 0.150 & 0.208 & 0.180 & 0.137 & 0.269 \\
\hline Slack & 0.168 & 0.084 & 0.198 & 0.126 & 0.064 & 0.155 & 0.229 & 0.141 & 0.235 \\
\hline FixedAssets & 0.314 & 0.253 & 0.229 & 0.358 & 0.311 & 0.223 & 0.249 & 0.168 & 0.221 \\
\hline Tax & 0.026 & 0.022 & 0.034 & 0.032 & 0.028 & 0.033 & 0.017 & 0.011 & 0.035 \\
\hline MB & 3.679 & 2.400 & 5.484 & 3.240 & 2.250 & 4.984 & 4.317 & 2.700 & 6.087 \\
\hline Size & 6.211 & 6.174 & 1.691 & 5.647 & 5.550 & 1.619 & 7.033 & 6.948 & 1.438 \\
\hline Leverage & 0.227 & 0.219 & 0.172 & 0.234 & 0.219 & 0.167 & 0.219 & 0.218 & 0.178 \\
\hline AssetGrowth & 0.466 & 0.180 & 2.618 & 0.525 & 0.220 & 3.254 & 0.379 & 0.110 & 1.185 \\
\hline StockVolat & 0.492 & 0.443 & 0.213 & 0.443 & 0.408 & 0.163 & 0.564 & 0.507 & 0.253 \\
\hline Proceeds & 0.350 & 0.229 & 0.404 & 0.350 & 0.246 & 0.372 & 0.349 & 0.219 & 0.447 \\
\hline DivYield & 0.008 & 0.000 & 0.016 & 0.011 & 0.000 & 0.017 & 0.004 & 0.000 & 0.015 \\
\hline \multicolumn{10}{|c|}{ Issue-Specific Characteristics } \\
\hline Delta & 0.7881 & 0.8396 & 0.1890 & 0.7731 & 0.8277 & 0.2088 & 0.8100 & 0.8562 & 0.1532 \\
\hline Predicted Delta & 0.5870 & 0.6074 & 0.2732 & 0.6430 & 0.6869 & 0.2507 & 0.5052 & 0.4935 & 0.2839 \\
\hline Design Surprise & 0.2011 & 0.1745 & 0.2689 & 0.1300 & 0.1058 & 0.2380 & 0.3047 & 0.3054 & 0.2778 \\
\hline Underpricing & 17.317 & 18.100 & 12.404 & 21.624 & 22.315 & 9.492 & 15.287 & 15.260 & 13.086 \\
\hline Announce. Return & -2.987 & -2.545 & 6.169 & -1.706 & -1.728 & 5.050 & -4.479 & -4.353 & 6.972 \\
\hline Investment grade $\%$ & 27.512 & & & 23.700 & & & 35.400 & & \\
\hline Not rated \% & 44.732 & & & 29.600 & & & 61.800 & & \\
\hline \multicolumn{10}{|c|}{ Macro-Wide Characteristics } \\
\hline Hedge Fund Flows & 0.030 & 0.041 & 0.042 & 0.027 & 0.028 & 0.025 & 0.031 & 0.047 & 0.047 \\
\hline Rate & 3.459 & 3.393 & 2.200 & 4.459 & 4.381 & 2.296 & 2.002 & 1.986 & 0.796 \\
\hline
\end{tabular}




\begin{tabular}{|c|c|c|c|c|c|c|c|c|c|}
\hline TermSpread & 1.755 & 1.800 & 1.263 & 1.793 & 1.753 & 1.211 & 1.699 & 2.037 & 1.333 \\
\hline MktRunup & 0.043 & 0.047 & 0.068 & 0.057 & 0.059 & 0.063 & 0.022 & 0.024 & 0.070 \\
\hline MktVolat & 0.146 & 0.136 & 0.049 & 0.138 & 0.135 & 0.038 & 0.159 & 0.144 & 0.059 \\
\hline Sentiment & 89.130 & 90.900 & 10.885 & 87.793 & 91.567 & 12.757 & 91.079 & 90.167 & 6.904 \\
\hline
\end{tabular}


Table 2: Summary statistics for convertible bond issuers by surprise magnitude This table shows issuer characteristics classified by whether the design surprise was above or below the median. Variables are defined in the appendix.

\begin{tabular}{|c|c|c|c|c|}
\hline & \multicolumn{2}{|c|}{$\begin{array}{l}\text { Pre-arb period (1975-1999) } \\
(\mathrm{N}=1,040)\end{array}$} & \multicolumn{2}{|c|}{$\begin{array}{l}\text { Arb period }(2000-2007) \\
(\mathrm{N}=716)\end{array}$} \\
\hline & High Surprise & Low Surprise & High Surprise & Low Surprise \\
\hline Delta & 0.807 & 0.714 & 0.831 & 0.753 \\
\hline Predicted Delta & 0.480 & 0.768 & 0.282 & 0.675 \\
\hline Design Surprise & 0.327 & -0.054 & 0.549 & 0.078 \\
\hline Issued SD previously & 0.605 & 0.159 & 0.932 & 0.382 \\
\hline Issued EQ Previously & 0.636 & 0.513 & 0.556 & 0.494 \\
\hline Investment grade $\%$ & 0.293 & 0.189 & 0.398 & 0.280 \\
\hline Not rated $\%$ & 0.144 & 0.322 & 0.429 & 0.760 \\
\hline Profitability & 0.075 & 0.064 & 0.040 & -0.030 \\
\hline Underpricing & 17.589 & 24.214 & 12.555 & 17.272 \\
\hline Announce. Return & -1.206 & -1.232 & -3.743 & -5.150 \\
\hline
\end{tabular}


Table 3: Analysis of the motivations to issue convertible debt instead of seasoned equity or straight debt

This table presents the results of a logistic analysis showing the effect of firm characteristics and aggregate financing costs on the decision to issue convertible debt instead of debt (Columns 1 to 3), and convertible debt instead of equity (Columns 4 to 6). The dependent variable in the logistic regression takes the value of 1 for convertible debt and 0 for seasoned equity issues or straight debt issues. The Pre-arbitrage period spans 1975-1995 and refers to the period before the surge in convertible arbitrage hedge funds, while the Arbitrage period spans 1996-2007 and refers to the era when convertible arbitrageurs were the predominant purchasers of convertible debt issues. The independent variables are measured as of the end of the fiscal year prior to the issue, unless otherwise stated (\# indicates a Compustat data item). Stock Run-up is the cumulative stock return over the window $(-120,-40)$ relative to the announcement date. Slack is calculated as cash and short-term investments (\# 1) divided by total assets (\# 6). Fixed Assets is calculated as plant, property and equipment (\# 8) divided by total assets. Tax is the tax liabilities benefit associated with issuing debt (\# 16) divided by total assets. $M B$ refers to the market to book value and is calculated as the number of shares (\# 24) multiplied by the share price (\# 25), divided by common equity (\# 60). Size is calculated as the natural logarithm of total assets (\# 6). Leverage is book leverage, measured as long-term debt (\# 9) divided by total assets. Asset Growth is calculated as the percentage growth in assets over the year prior to the offering. Stock Volat is the annualized standard deviation of the stock return, calculated using daily returns over the window $(-120,-40)$ relative to the announcement date. Div Yield is defined as dividend per share (\# 26) divided by the stock price (\# 199). Rate refers to the quarterly average real interest rate, measured as the difference between yields on 10-year Treasury Bonds and the inflation rate. Term Spread refers to the quarterly average term premium, calculated as the difference between yields on 10-year Treasury Bonds and 3-month Treasury Bills. Mkt Run-up captures the quarterly return on the S\&P 500 Index. Mkt Volat is the annualized market return volatility calculated from daily returns on the S\&P 500 index averaged over the quarter. $t$ statistics, estimated using Huber-White robust standard errors, are in parentheses. ${ }^{*},{ }^{* *},{ }^{* *}$ indicate significance at the $10 \%, 5 \%$, and $1 \%$ level, respectively. 


\begin{tabular}{|c|c|c|c|c|c|c|}
\hline & Cho & oice $\mathrm{b}$ & etween conve & erible & and debt & \\
\hline & Entrire period & & Pre-arb peri & iod & Arb period & \\
\hline & (1) & & (2) & & (3) & \\
\hline Hedge Fund Flows & $\begin{array}{r}4.19 \\
(3.72)\end{array}$ & $* * *$ & $\begin{array}{r}2.41 \\
(0.96)\end{array}$ & & $\begin{array}{r}3.27 \\
(2.44)\end{array}$ & $* *$ \\
\hline Firm-Specific Chara & & & & & & \\
\hline StockRunup & $\begin{array}{r}0.48 \\
(4.41)\end{array}$ & $* * *$ & $\begin{array}{r}0.79 \\
(3.97)\end{array}$ & $* * *$ & $\begin{array}{r}0.33 \\
(2.36)\end{array}$ & $* *$ \\
\hline Slack & $\begin{array}{r}5.46 \\
(12.38)\end{array}$ & $* * *$ & $\begin{array}{r}4.59 \\
(7.05)\end{array}$ & $* * *$ & $\begin{array}{r}6.54 \\
(11.03)\end{array}$ & $* * *$ \\
\hline FixedAssets & $\begin{array}{r}-0.72 \\
(-3.91)\end{array}$ & $* * *$ & $\begin{array}{r}-0.97 \\
(-3.33)\end{array}$ & $* * *$ & $\begin{array}{r}-0.49 \\
(-2.06)\end{array}$ & $* *$ \\
\hline Tax & $\begin{array}{r}-9.36 \\
(-5.90)\end{array}$ & $* * *$ & $\begin{array}{l}-10.50 \\
(-3.91)\end{array}$ & $* * *$ & $\begin{array}{r}-9.22 \\
(-4.67)\end{array}$ & $* * *$ \\
\hline MB & $\begin{array}{r}0.00 \\
(0.22)\end{array}$ & & $\begin{array}{r}0.00 \\
(-0.26)\end{array}$ & & $\begin{array}{r}0.00 \\
(0.11)\end{array}$ & \\
\hline Size & $\begin{array}{r}-0.39 \\
(-13.46)\end{array}$ & $* * *$ & $\begin{array}{r}-0.48 \\
(-9.89)\end{array}$ & $* * *$ & $\begin{array}{r}-0.45 \\
(-10.97)\end{array}$ & $* * *$ \\
\hline Leverage & $\begin{array}{r}-1.94 \\
(-7.06)\end{array}$ & $* * *$ & $\begin{array}{r}-1.56 \\
(-3.87)\end{array}$ & $* * *$ & $\begin{array}{r}-2.17 \\
(-5.78)\end{array}$ & $* * *$ \\
\hline AssetGrowth & $\begin{array}{r}0.12 \\
(2.57)\end{array}$ & $* * *$ & $\begin{array}{r}0.09 \\
(1.91)\end{array}$ & $*$ & $\begin{array}{r}0.22 \\
(2.10)\end{array}$ & $* *$ \\
\hline StockVolat & $\begin{array}{r}2.12 \\
(7.49)\end{array}$ & $* * *$ & $\begin{array}{r}0.62 \\
(1.23)\end{array}$ & & $\begin{array}{r}2.61 \\
(7.93)\end{array}$ & $* * *$ \\
\hline Macro-Wide Charact & & & & & & \\
\hline Rate $_{t-1}$ & $\begin{array}{r}-0.38 \\
(-9.54)\end{array}$ & $* * *$ & $\begin{array}{r}-0.15 \\
(-1.07)\end{array}$ & & $\begin{array}{r}-0.11 \\
(-1.44)\end{array}$ & \\
\hline TermSpread $_{t-1}$ & $\begin{array}{r}0.02 \\
(0.58)\end{array}$ & & $\begin{array}{r}0.20 \\
(1.66)\end{array}$ & $*$ & $\begin{array}{r}-0.09 \\
(-2.15)\end{array}$ & $* *$ \\
\hline MktRunup $_{t-1}$ & $\begin{array}{r}-0.85 \\
(-1.32)\end{array}$ & & $\begin{array}{r}-0.55 \\
(-0.48)\end{array}$ & & $\begin{array}{r}1.23 \\
(1.37)\end{array}$ & \\
\hline MktVolat $_{\mathrm{t}-1}$ & $\begin{array}{r}-3.77 \\
(-4.62)\end{array}$ & $* * *$ & $\begin{array}{r}-4.66 \\
(-2.66)\end{array}$ & $* * *$ & $\begin{array}{r}-2.50 \\
(-2.38)\end{array}$ & $* *$ \\
\hline Intercept & $\begin{array}{r}2.61 \\
(7.42)\end{array}$ & $* * *$ & $\begin{array}{r}2.79 \\
(3.62)\end{array}$ & $* * *$ & $\begin{array}{r}2.27 \\
(5.17)\end{array}$ & $* * *$ \\
\hline $\begin{array}{l}\text { Adjusted R-squared } \\
\text { No. of Observations }\end{array}$ & $\begin{array}{r}33.3 \\
6,348\end{array}$ & $\%$ & $\begin{array}{r}30.1 \\
3,305\end{array}$ & $\%$ & $\begin{array}{r}34.5 \\
3,043\end{array}$ & $\%$ \\
\hline
\end{tabular}


Table 3 continued

\begin{tabular}{|c|c|c|c|c|c|c|}
\hline & Choi & ice be & ween conve & ribles & and Equity & \\
\hline & Entrire period & & Pre-arb per & iod & Arb period & \\
\hline & (4) & & (5) & & (6) & \\
\hline Hedge Fund Flows & $\begin{array}{r}2.83 \\
(3.03)\end{array}$ & $* * *$ & $\begin{array}{r}2.68 \\
(1.22)\end{array}$ & & $\begin{array}{r}4.08 \\
(3.50)\end{array}$ & $* * *$ \\
\hline Firm-Specific Chara & & & & & & \\
\hline StockRunup & $\begin{array}{r}-0.57 \\
(-7.10)\end{array}$ & $* * *$ & $\begin{array}{r}-0.92 \\
(-6.22)\end{array}$ & $* * *$ & $\begin{array}{r}-0.34 \\
(-3.53)\end{array}$ & $* * *$ \\
\hline Slack & $\begin{array}{r}0.67 \\
(3.64)\end{array}$ & $* * *$ & $\begin{array}{r}0.80 \\
(2.83)\end{array}$ & $* * *$ & $\begin{array}{r}0.79 \\
(3.27)\end{array}$ & $* * *$ \\
\hline FixedAssets & $\begin{array}{r}-0.73 \\
(-4.31)\end{array}$ & $* * *$ & $\begin{array}{r}-0.45 \\
(-1.70)\end{array}$ & $*$ & $\begin{array}{r}-1.01 \\
(-4.49)\end{array}$ & $* * *$ \\
\hline Tax & $\begin{array}{r}-0.87 \\
(-0.75)\end{array}$ & & $\begin{array}{r}-4.69 \\
(-2.47)\end{array}$ & $* *$ & $\begin{array}{r}1.14 \\
(0.74)\end{array}$ & \\
\hline $\mathrm{MB}$ & $\begin{array}{r}0.00 \\
(-0.38)\end{array}$ & & $\begin{array}{r}0.00 \\
(-0.05)\end{array}$ & & $\begin{array}{r}0.00 \\
(-0.09)\end{array}$ & \\
\hline Size & $\begin{array}{r}0.53 \\
(17.64)\end{array}$ & $* * *$ & $\begin{array}{r}0.44 \\
(9.78)\end{array}$ & $* * *$ & $\begin{array}{r}0.65 \\
(14.54)\end{array}$ & $* * *$ \\
\hline Leverage & $\begin{array}{r}-0.69 \\
(-3.00)\end{array}$ & $* * *$ & $\begin{array}{r}-0.48 \\
(-1.29)\end{array}$ & & $\begin{array}{r}-1.08 \\
(-3.55)\end{array}$ & $* * *$ \\
\hline AssetGrowth & $\begin{array}{r}0.03 \\
(2.09)\end{array}$ & $* *$ & $\begin{array}{r}0.04 \\
(2.21)\end{array}$ & $* *$ & $\begin{array}{r}-0.02 \\
(-0.53)\end{array}$ & \\
\hline StockVolat & $\begin{array}{r}1.37 \\
(7.15)\end{array}$ & $* * *$ & $\begin{array}{r}1.51 \\
(5.20)\end{array}$ & $* * *$ & $\begin{array}{r}1.17 \\
(4.96)\end{array}$ & $* * *$ \\
\hline Macro-Wide Charact & & & & & & \\
\hline Rate $_{t-1}$ & $\begin{array}{r}-0.10 \\
(-2.83)\end{array}$ & $* * *$ & $\begin{array}{r}0.09 \\
(0.70)\end{array}$ & & $\begin{array}{r}-0.23 \\
(-3.52)\end{array}$ & $* * *$ \\
\hline TermSpread $_{t-1}$ & $\begin{array}{r}-0.02 \\
(-0.58)\end{array}$ & & $\begin{array}{r}-0.07 \\
(-0.63)\end{array}$ & & $\begin{array}{r}-0.05 \\
(-1.35)\end{array}$ & \\
\hline MktRunup $_{\mathrm{t}-1}$ & $\begin{array}{r}2.40 \\
(3.74)\end{array}$ & $* * *$ & $\begin{array}{r}1.37 \\
(1.05)\end{array}$ & & $\begin{array}{r}3.48 \\
(4.15)\end{array}$ & $* * *$ \\
\hline MktVolat $_{t-1}$ & $\begin{array}{r}-1.01 \\
(-1.31)\end{array}$ & & $\begin{array}{r}-2.60 \\
(-1.57)\end{array}$ & & $\begin{array}{r}0.64 \\
(0.65)\end{array}$ & \\
\hline Intercept & $\begin{array}{r}-4.13 \\
(-14.75)\end{array}$ & $* * *$ & $\begin{array}{r}-3.99 \\
(-6.02)\end{array}$ & $* * *$ & $\begin{array}{r}-4.74 \\
(-12.88)\end{array}$ & $* * *$ \\
\hline $\begin{array}{l}\text { Adjusted R-squared } \\
\text { No. of Observations }\end{array}$ & $\begin{array}{r}12.6 \\
4,308\end{array}$ & $\%$ & $\begin{array}{r}9.9 \\
1,986\end{array}$ & $\%$ & $\begin{array}{r}14.3 \\
2,322\end{array}$ & $\%$ \\
\hline
\end{tabular}


Table 4: Analysis of the design of convertible debt offerings

This table presents the results of an OLS pooled regression showing the effect of firm characteristics and aggregate financing costs on the structure of convertible offerings using firm-level data. The dependent variable in the regression is delta (Columns 1 to 3), and vega (Columns 4 to 6). delta measures the sensitivity of the convertible bond value to movements in the underlying share price. vega measures the sensitivity of the convertible bond value to movements in the volatility of the stock returns. The Pre-arbitrage period spans 1975-1995 and refers to the period before the surge in convertible arbitrage hedge funds, while the Arbitrage period spans 1996-2007 and refers to the era when convertible arbitrageurs were the predominant purchasers of convertible debt issues. The independent variables are measured as of the end of the fiscal year prior to the issue, unless otherwise stated (\# indicates a Compustat data item). Stock Run-up is the cumulative stock return over the window $(-120,-40)$ relative to the announcement date. Slack is calculated as cash and short-term investments (\# 1) divided by total assets (\# 6). Fixed Assets is calculated as plant, property and equipment (\# 8) divided by total assets. Tax is the tax liabilities benefit associated with issuing debt (\# 16) divided by total assets. $M B$ refers to the market to book value and is calculated as the number of shares (\# 24) multiplied by the share price (\# 25), divided by common equity (\# 60). Size is calculated as the natural logarithm of total assets (\# 6). Leverage is book leverage, measured as long-term debt (\# 9) divided by total assets. Asset Growth is calculated as the percentage growth in assets over the year prior to the offering. Stock Volat is the annualized standard deviation of the stock return, calculated using daily returns over the window $(-120,-40)$ relative to the announcement date. Rate refers to the quarterly average real interest rate, measured as the difference between yields on 10-year Treasury Bonds and the inflation rate. Term Spread refers to the quarterly average term premium, calculated as the difference between yields on 10-year Treasury Bonds and 3-month Treasury Bills. Mkt Run-up captures the quarterly return on the S\&P 500 Index. Mkt Volat is the annualized market return volatility calculated from daily returns on the S\&P 500 index averaged over the quarter. $t$ statistics, estimated using heteroskedasticity-consitent White standard errors, are in parentheses. ${ }^{* * *},{ }^{* * *}$ indicate significance at the $10 \%, 5 \%$, and $1 \%$ level, respectively. 


\begin{tabular}{|c|c|c|c|c|c|c|c|c|}
\hline & \multicolumn{4}{|c|}{ Delta } & \multicolumn{4}{|c|}{ Design Surprise } \\
\hline & \multicolumn{2}{|l|}{ (1) } & \multicolumn{2}{|l|}{ (2) } & \multicolumn{2}{|c|}{ (3) } & \multicolumn{2}{|l|}{ (4) } \\
\hline Hedge Fund Flows & & & $\begin{array}{r}0.21 \\
(1.84)\end{array}$ & $* *$ & & & $\begin{array}{r}0.40 \\
(2.62)\end{array}$ & $* * *$ \\
\hline \multicolumn{9}{|c|}{ Firm-Specific Characteristics } \\
\hline StockRunup & $\begin{array}{r}0.04 \\
(2.25)\end{array}$ & $* *$ & $\begin{array}{r}0.05 \\
(3.50)\end{array}$ & $* * *$ & $\begin{array}{r}-0.05 \\
(-2.33)\end{array}$ & $* *$ & $\begin{array}{r}-0.03 \\
(-1.09)\end{array}$ & \\
\hline Slack & $\begin{array}{r}0.07 \\
(3.57)\end{array}$ & $* * *$ & $\begin{array}{r}0.03 \\
(1.38)\end{array}$ & & $\begin{array}{r}-0.25 \\
(-9.77)\end{array}$ & $* * *$ & $\begin{array}{r}-0.29 \\
(-9.88)\end{array}$ & $* * *$ \\
\hline FixedAssets & $\begin{array}{r}-0.03 \\
(-1.58)\end{array}$ & & $\begin{array}{r}0.03 \\
(1.38)\end{array}$ & & $\begin{array}{r}-0.03 \\
(-1.09)\end{array}$ & & $\begin{array}{r}0.03 \\
(0.97)\end{array}$ & \\
\hline $\operatorname{Tax}$ & $\begin{array}{r}0.18 \\
(1.50)\end{array}$ & & $\begin{array}{r}0.13 \\
(1.10)\end{array}$ & & $\begin{array}{r}0.84 \\
(5.75)\end{array}$ & $* * *$ & $\begin{array}{r}0.94 \\
(5.11)\end{array}$ & $* * *$ \\
\hline MB & $\begin{array}{r}0.00 \\
(1.60)\end{array}$ & & $\begin{array}{r}0.00 \\
(0.28)\end{array}$ & & $\begin{array}{r}0.00 \\
(-0.31)\end{array}$ & & $\begin{array}{r}0.00 \\
(-2.12)\end{array}$ & $* *$ \\
\hline Size & $\begin{array}{r}-0.03 \\
(-11.48)\end{array}$ & $* * *$ & $\begin{array}{r}-0.02 \\
(-3.45)\end{array}$ & $* * *$ & $\begin{array}{r}0.10 \\
(27.98)\end{array}$ & $* * *$ & $\begin{array}{r}0.11 \\
(15.01)\end{array}$ & $* * *$ \\
\hline Leverage & $\begin{array}{r}0.06 \\
(2.17)\end{array}$ & $* *$ & $\begin{array}{r}-0.02 \\
(-0.61)\end{array}$ & & $\begin{array}{r}0.12 \\
(3.88)\end{array}$ & $* * *$ & $\begin{array}{r}0.08 \\
(2.07)\end{array}$ & $* *$ \\
\hline AssetGrowth & $\begin{array}{r}0.00 \\
(0.49)\end{array}$ & & $\begin{array}{r}0.00 \\
(-0.75)\end{array}$ & & $\begin{array}{r}0.00 \\
(-0.43)\end{array}$ & & $\begin{array}{r}0.00 \\
(-1.42)\end{array}$ & \\
\hline StockVolat & $\begin{array}{r}0.04 \\
(12.00)\end{array}$ & $* * *$ & $\begin{array}{r}0.02 \\
(6.06)\end{array}$ & $* * *$ & $\begin{array}{r}0.03 \\
(7.14)\end{array}$ & $* * *$ & $\begin{array}{r}0.01 \\
(1.38)\end{array}$ & \\
\hline Intercept & $\begin{array}{r}0.81 \\
(31.75)\end{array}$ & $* * *$ & $\begin{array}{r}0.81 \\
(20.22)\end{array}$ & $* * *$ & $\begin{array}{r}-0.52 \\
(-15.23)\end{array}$ & $* * *$ & $\begin{array}{r}-0.50 \\
(-8.05)\end{array}$ & $* * *$ \\
\hline Adjusted R-squared & 22.2 & $\%$ & 15.5 & $\%$ & 44.1 & $\%$ & 61.1 & $\%$ \\
\hline No. of Observations & 1,545 & & 722 & & 1,545 & & 722 & \\
\hline
\end{tabular}




\section{Table 5: Underpricing of convertible debt offerings}

This table presents the results of regressions of convertible debt underpricing on investor demand proxies and control variables. The dependent variable is the percentage underpricing of each convertible debt offering, calculated using the model of Tsiveriotis and Fernandes (1998). Investor demand variables and aggregate financing costs measures are calculated over the quarter preceding the convertible bond issue date. RiskAversion is a habitat-based risk aversion proxy calculated as in Campbell and Cochrane (1999). OptionDemand measures the difference between implied and realized volatilities as in Garleanu, Pedersen, and Poteshman (2009). OverAllot is the number of convertibles for which the over-allotment option is exercised relative to all convertible bond offerings in each quarter. AbnRet captures average abnormal stock returns measured over the window $(-1,1)$ relative to the announcement date using standard event study methodology. Mflows measures quarterly flows into convertible mutual funds, obtained from the CRSP Survivorship-Bias Free Mutual Fund Database. Hflows measures quarterly flows into convertible arbitrage hedge funds, obtained from the TASS Live and Graveyard subdatabases. Rate refers to the quarterly average real interest rate, measured as the difference between yields on 10-year Treasury Bonds and the inflation rate. TermSpread refers to the quarterly average term premium, calculated as the difference between yields on 10-year Treasury Bonds and 3-month Treasury Bills. MktRunup captures the quarterly return on the S\&P 500 Index. MktVolat is the annualized market return volatility calculated from daily returns on the S\&P 500 index averaged over the quarter. Sentiment is the quarterly average level of the Michigan Consumer Sentiment Index. Firm-specific and issue-specific characteristics are measured as of the end of the fiscal year prior to the issue, unless otherwise stated (\# refers to Compustat data items). StockRunup is the cumulative stock return over the window $(-240,-40)$ relative to the announcement date. StockVolat is the annualized standard deviation of the stock return, calculated using daily returns over the window $(-240,-40)$ relative to the announcement date. Size is the natural logarithm of total assets (\# 6). DivYield is defined as dividend per share (\# 26) divided by the stock price (\# 199). TradingVolume is the average trading volume of the stock over trading days -240 to -40 deflated by the average equity market value over that period. Dilution is defined as the number of additional shares issued upon conversion divided by the total numbers of shares outstanding at the time of issuance. Moneyness is the conversion value divided by the investment value. Maturity is the final maturity date of the convertible. Rating represents a scaled measure for the bond rating, ranging from 1 for bonds rated AAA by Moody's to 15 for bonds rated B2 or below. The starting period varies, but all data span until end-2007. All regressions include year-fixed effects and are estimated using Generalised Least Squares, with weights based on the number of annual observations. $t$-statistics (calculated with standard errors robust to clustering of observations within each year) are in parentheses. ${ }^{*},{ }^{* * *},{ }^{* * *}$ indicate significance at the $10 \%, 5 \%$, and $1 \%$ level, respectively. 


\begin{tabular}{|c|c|c|c|c|c|c|c|}
\hline & $\begin{array}{c}\text { Entrire period } \\
\text { (1) }\end{array}$ & $\begin{array}{c}\text { Pre-arb } \\
\text { (2) }\end{array}$ & $\begin{array}{c}\text { Post-arb } \\
\text { (3) }\end{array}$ & $\begin{array}{c}\text { Entrire period } \\
\text { (4) }\end{array}$ & $\begin{array}{c}\text { Pre-arb } \\
(5)\end{array}$ & $\begin{array}{c}\text { Post-arb } \\
(6)\end{array}$ & $\begin{array}{c}\text { Entrire period } \\
(7)\end{array}$ \\
\hline \multicolumn{8}{|l|}{ Design } \\
\hline Design Surprise & $\begin{array}{l}4.51 \text { ** } \\
(2.19)\end{array}$ & $\begin{array}{l}8.89 * * \\
(2.28)\end{array}$ & $\begin{array}{c}3.92 * \\
(1.88)\end{array}$ & & & & \\
\hline Delta & & & & $\begin{array}{l}17.04 * * * \\
(4.66)\end{array}$ & $\begin{array}{l}45.42 * * * \\
(3.80)\end{array}$ & $\begin{array}{l}13.46^{* * *} \\
(3.46)\end{array}$ & $\begin{array}{l}25.13 * * * \\
(4.93)\end{array}$ \\
\hline \multicolumn{8}{|c|}{ Macro-Wide Characteristics } \\
\hline Rate & $\begin{array}{l}-1.10 * * \\
(-2.14)\end{array}$ & $\begin{array}{r}-0.32 \\
(-0.41)\end{array}$ & $\begin{array}{l}-1.65 * * * \\
(-2.60)\end{array}$ & $\begin{array}{l}-1.01 * \\
(-1.90)\end{array}$ & $\begin{array}{r}-0.14 \\
(-0.18)\end{array}$ & $\begin{array}{l}-1.59 * * \\
(-2.40)\end{array}$ & $\begin{array}{l}-0.32 * * \\
(-0.48)\end{array}$ \\
\hline TermSpread & $\begin{array}{r}0.66 \\
(1.21)\end{array}$ & $\begin{array}{r}0.86 \\
(0.68)\end{array}$ & $\begin{array}{c}1.11 * \\
(1.69)\end{array}$ & $\begin{array}{r}0.46 \\
(0.89)\end{array}$ & $\begin{array}{r}-0.32 \\
(-0.30)\end{array}$ & $\begin{array}{r}0.93 \\
(1.52)\end{array}$ & $\begin{array}{r}0.03 \\
(0.04)\end{array}$ \\
\hline MktRunup & $\begin{array}{r}-0.72 \\
(-0.15)\end{array}$ & $\begin{array}{l}-16.29 * * * \\
(-2.81)\end{array}$ & $\begin{array}{r}8.87 \\
(1.52)\end{array}$ & $\begin{array}{r}-3.43 \\
(-0.76)\end{array}$ & $\begin{array}{l}-16.12 * * * \\
(-3.18)\end{array}$ & $\begin{array}{r}4.48 \\
(0.81)\end{array}$ & $\begin{array}{r}-3.70 \\
(-0.79)\end{array}$ \\
\hline MktVolat & $\begin{array}{l}-18.29 * * \\
(-2.01)\end{array}$ & $\begin{array}{r}-0.87 \\
(-0.10)\end{array}$ & $\begin{array}{l}-26.39 * * \\
(-2.24)\end{array}$ & $\begin{array}{l}-21.69 * * \\
(-2.52)\end{array}$ & $\begin{array}{r}3.39 \\
(0.40)\end{array}$ & $\begin{array}{l}-33.37 * * * \\
(-2.94)\end{array}$ & $\begin{array}{l}-22.21 \\
(-2.42)\end{array}$ \\
\hline Sentiment & $\begin{array}{l}0.12 * \\
(1.75)\end{array}$ & $\begin{array}{l}-0.17 * \\
(-1.71)\end{array}$ & $\begin{array}{l}0.22 * * \\
(2.31)\end{array}$ & $\begin{array}{l}0.10 * \\
(1.78)\end{array}$ & $\begin{array}{c}-0.14 * \\
(-1.73)\end{array}$ & $\begin{array}{l}0.18 * * \\
(2.18)\end{array}$ & $\begin{array}{l}0.11 * * \\
(1.54)\end{array}$ \\
\hline Hedge Fund Flows & & & & & & & $\begin{array}{l}-23.25 * * * \\
(-2.99)\end{array}$ \\
\hline \multicolumn{8}{|c|}{ Firm-Specific Characteristics } \\
\hline StockRunup & $\begin{array}{r}0.25 \\
(0.41)\end{array}$ & $\begin{array}{r}0.39 \\
(0.41)\end{array}$ & $\begin{array}{r}0.24 \\
(0.33)\end{array}$ & $\begin{array}{r}-0.38 \\
(-0.87)\end{array}$ & $\begin{array}{r}-0.81 \\
(-1.64)\end{array}$ & $\begin{array}{r}-0.35 \\
(-0.65)\end{array}$ & $\begin{array}{r}-0.40 \\
(-0.87)\end{array}$ \\
\hline StockVolat & $\begin{array}{l}17.48 \text { **** } \\
(11.11)\end{array}$ & $\begin{array}{l}17.44 * * * \\
(8.74)\end{array}$ & $\begin{array}{l}17.00 * * * \\
(10.20)\end{array}$ & $\begin{array}{l}13.09 * * * \\
(7.53)\end{array}$ & $\begin{array}{l}5.51 * \\
(1.82)\end{array}$ & $\begin{array}{l}13.39 * * * \\
(7.28)\end{array}$ & $\begin{array}{l}10.66^{* * *} \\
(6.09)\end{array}$ \\
\hline LogAssets & $\begin{array}{l}-2.29 * * * \\
(-6.42)\end{array}$ & $\begin{array}{l}-3.10 * * * \\
(-4.70)\end{array}$ & $\begin{array}{l}-1.89 * * * \\
(-4.63)\end{array}$ & $\begin{array}{l}-1.23 * * * \\
(-6.55)\end{array}$ & $\begin{array}{l}-1.33 * * * \\
(-5.60)\end{array}$ & $\begin{array}{l}-1.02 * * * \\
(-3.65)\end{array}$ & $\begin{array}{l}-1.31 * * * \\
(-6.27)\end{array}$ \\
\hline DivYield & $\begin{array}{l}-38.78 * * \\
(-2.13)\end{array}$ & $\begin{array}{l}-117.53 * * * \\
(-3.39)\end{array}$ & $\begin{array}{l}-11.91 \\
(-0.74)\end{array}$ & $\begin{array}{l}25.81 \\
(1.18)\end{array}$ & $\begin{array}{r}117.09 \\
(1.22)\end{array}$ & $\begin{array}{l}33.05 \\
(1.31)\end{array}$ & $\begin{array}{l}174.41 * * \\
(2.35)\end{array}$ \\
\hline \multicolumn{8}{|c|}{ Issue-Specific Characteristics } \\
\hline Dilution & $\begin{array}{l}11.71 * * * \\
(3.49)\end{array}$ & $\begin{array}{l}5.26 \text { *** } \\
(4.17)\end{array}$ & $\begin{array}{l}24.59 * * * \\
(6.10)\end{array}$ & $\begin{array}{l}13.36 * * * \\
(4.29)\end{array}$ & $\begin{array}{l}5.80 * * * \\
(5.13)\end{array}$ & $\begin{array}{l}24.13 * * * \\
(8.04)\end{array}$ & $\begin{array}{l}12.91 * * * \\
(3.58)\end{array}$ \\
\hline Moneyness & $\begin{array}{l}-11.12 * * * \\
(-8.00)\end{array}$ & $\begin{array}{l}-11.19 * * * \\
(-12.72)\end{array}$ & $\begin{array}{l}-10.59 * * * \\
(-6.70)\end{array}$ & $\begin{array}{l}-11.97 * * * \\
(-8.66)\end{array}$ & $\begin{array}{l}-13.53 * * * \\
(-16.68)\end{array}$ & $\begin{array}{l}-11.30 * * * \\
(-7.07)\end{array}$ & $\begin{array}{l}-13.69 * * * \\
(-15.43)\end{array}$ \\
\hline Maturity & $\begin{array}{l}0.12 * * * \\
(2.70)\end{array}$ & $\begin{array}{l}0.45 * * * \\
(2.99)\end{array}$ & $\begin{array}{r}0.08 \\
(1.55)\end{array}$ & $\begin{array}{r}0.02 \\
(0.33)\end{array}$ & $\begin{array}{r}0.24 \\
(1.25)\end{array}$ & $\begin{array}{r}-0.01 \\
(-0.14)\end{array}$ & $\begin{array}{r}-0.02 \\
(-0.36)\end{array}$ \\
\hline Rating & $\begin{array}{l}-0.68 * * * \\
(-5.75)\end{array}$ & $\begin{array}{l}-0.37 * * * \\
(-3.91)\end{array}$ & $\begin{array}{l}-0.89 * * * \\
(-5.78)\end{array}$ & $\begin{array}{l}-0.69 * * * \\
(-5.82)\end{array}$ & $\begin{array}{l}-0.35 * * * \\
(-3.97)\end{array}$ & $\begin{array}{l}-0.90 * * * \\
(-5.92)\end{array}$ & $\begin{array}{l}-0.54 * * * \\
(-5.71)\end{array}$ \\
\hline Intercept & $\begin{array}{l}35.18 * * * \\
(4.72)\end{array}$ & $\begin{array}{l}61.10^{* * *} \\
(6.00)\end{array}$ & $\begin{array}{l}22.95 * * \\
(2.18)\end{array}$ & $\begin{array}{l}22.72 * * * \\
(3.41)\end{array}$ & $\begin{array}{l}24.25 * * \\
(2.08)\end{array}$ & $\begin{array}{l}16.89 * \\
(1.84)\end{array}$ & $\begin{array}{l}17.73^{* *} \\
(2.14)\end{array}$ \\
\hline Adjusted R-squared & $69.2 \%$ & $69.7 \%$ & $70.9 \%$ & $69.3 \%$ & $69.5 \%$ & $72.9 \%$ & $74.2 \%$ \\
\hline No. of Observations & 905 & 290 & 615 & 905 & 290 & 615 & 846 \\
\hline Starting period & 1991 & 1991 & 1991 & 1991 & 1991 & 1991 & 1994 \\
\hline
\end{tabular}




\section{Table 6: Wealth effects of convertible debt offerings}

This table presents the results of a weighted least squares regression showing the effect of firm characteristics and aggregate financing costs on the structure of convertible offerings using firm-level data. The weight for each observation is the inverse of the standard deviation of the corresponding market model residual calculated over the window (-240, 40). The dependent variable in the regression is AbnRet, which captures the percentage abnormal stock returns measured over the window $(-1,0)$ relative to the announcement date using standard event study methodology. The Pre-arbitrage period spans 1975-1999 and refers to the period before the surge in convertible arbitrage hedge funds, while the Arbitrage period spans 2000-2007 and refers to the era when convertible arbitrageurs were the predominant purchasers of convertible debt issues. The independent variables are measured as of the end of the fiscal year prior to the issue, unless otherwise stated (\# indicates a Compustat data item). Stock Run-up is the cumulative stock return over the window $(-120,-40)$ relative to the announcement date. Slack is calculated as cash and short-term investments (\# 1) divided by total assets (\# 6). Fixed Assets is calculated as plant, property and equipment (\# 8) divided by total assets. Tax is the tax liabilities benefit associated with issuing debt (\# 16) divided by total assets. $M B$ refers to the market to book value and is calculated as the number of shares (\# 24) multiplied by the share price (\# 25), divided by common equity (\# 60). Size is calculated as the natural logarithm of total assets (\# 6). Leverage is book leverage, measured as long-term debt (\# 9) divided by total assets. Asset Growth is calculated as the percentage growth in assets over the year prior to the offering. Stock Volat is the annualized standard deviation of the stock return, calculated using daily returns over the window $(-120,-40)$ relative to the announcement date. Proceeds measures the relative size of the convertible debt offering, calculated as the issue proceeds divided by the total assets of the firm (\# 6). Delta measures the sensitivity of the convertible bond value to movements in the underlying share price. Rate refers to the quarterly average real interest rate, measured as the difference between yields on 10-year Treasury Bonds and the inflation rate. Term Spread refers to the quarterly average term premium, calculated as the difference between yields on 10-year Treasury Bonds and 3-month Treasury Bills. Mkt Run-up captures the quarterly return on the S\&P 500 Index. Mkt Volat is the annualized market return volatility calculated from daily returns on the S\&P 500 index averaged over the quarter. All regressions include year-fixed effects and are estimated using Generalised Least Squares, with weights based on the number of annual observations. $t$-statistics (calculated with standard errors robust to clustering of observations within each year) are in parentheses. ${ }^{*},{ }^{* * * * *}$ indicate significance at the $10 \%, 5 \%$, and $1 \%$ level, respectively. 


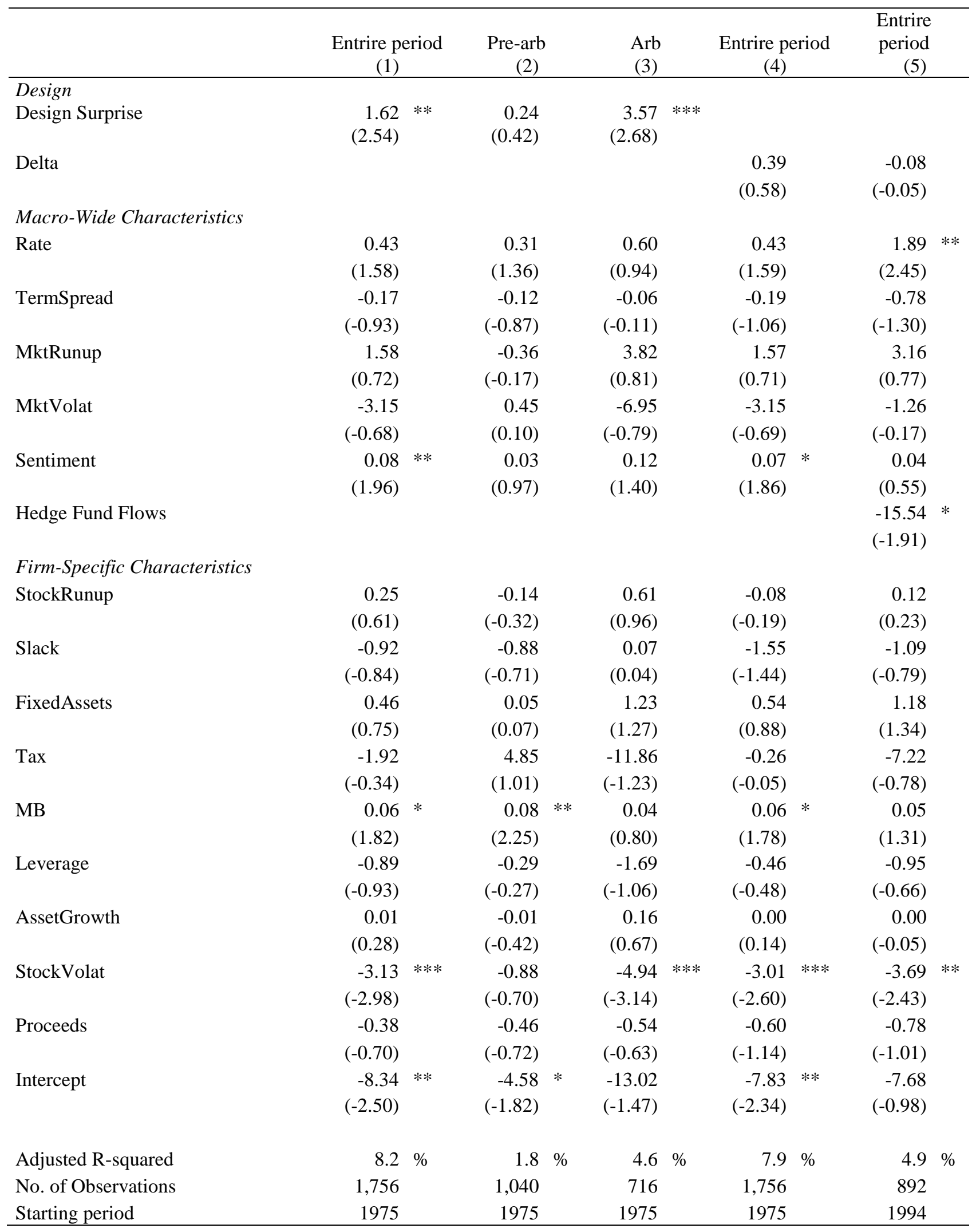

